\title{
JUS BUAH JAMBU BIJI MERAH (Psidium guajava L.) DAPAT MENURUNKAN SKOR ATHEROGENIC INDEX OF PLASMA
}

\section{(Red guava juices (Psidium guajava L.) reduced atherogenic index of plasma score)}

\author{
Riva Mustika Anugrah ${ }^{1 *}$, Kusmiyati Tjahjono ${ }^{2}$, Martha Irene Kartasurya ${ }^{3}$ \\ ${ }^{1}$ Departemen Ilmu Gizi, Fakultas Kedokteran Universitas Diponegoro, Semarang 50275 \\ ${ }^{2}$ Bagian Biokimia Fakultas Kedokteran Universitas Diponegoro, Semarang 50275 \\ ${ }^{3}$ Bagian Gizi Fakultas Kesehatan Masyarakat Universitas Diponegoro, Semarang 50275
}

\begin{abstract}
Objective of this research was to investigate the effect of red guava juices (Psidium guajava L) on score Atherogenic Index of Plasma (AIP) on toll collectors. Experimental studies with randomized pre-post control group design. Subjects were selected by clustered random sampling. Subjects is Fourthy toll collectors in Semarang. The treatment group received $250 \mathrm{ml}$ red guava juice for 21 days while the control group did not. Measurement of score AIP with log(Triglyceride (Test GPO) \& High Density Lipoprotein (HDL) (CHOD-PAP)) before and after study, food intake was measured by $3 \times 24$ recall hours. Data analysis by paired t-test \& independent t-test, Wilcoxon \& Mann Whitney test general linear model. The effect of red guava juice to AIP scores was not significant before controlled by age, level of carbohydrate intake and initial conditions $(p>0.05)$. Multivariate analysis showed that the effect of red guava juice to AIP score was significant after controlled by age, carbohydrate intake and initial conditions $(p<0.05)$.
\end{abstract}

Keywords: AIP Scores, HDL, red guava juice, triglyceride

\begin{abstract}
ABSTRAK
Tujuan dari penelitian ini adalah mengetahui pengaruh pemberian jus buah jambu biji merah terhadap skor Atherogenic Index of Plasma (AIP) pada petugas tiket tol. Studi eksperimen dengan randomized pre-post control group design. Subjek sejumlah 40 petugas tiket tol di Semarang dipilih dengan clustered random sampling. Kelompok perlakuan diberi $250 \mathrm{ml}$ jus buah jambu biji merah selama 21 hari dan kelompok kontrol tidak diberi intervensi. Perhitungan skor AIP dengan log (Trigliserida (metode GPO) \& High Density Lipoprotein (HDL) (metode CHOD-PAP)) diukur pada awal dan akhir penelitian, asupan makan diukur dengan recall 3 × 24 jam/minggu. Analisis data dilakukan dengan uji t berpasangan \& uji t tidak berpasangan, uji Wilcoxon, Mann Whitney, dan General Linear Model. Tidak terdapat pengaruh pemberian jus buah jambu biji merah terhadap skor AIP sebelum dikontrol oleh usia, tingkat asupan karbohidrat dan kondisi awal $(\mathrm{p}>0,05)$. Uji multivariat menunjukan ada pengaruh pemberian jus buah jambu biji merah terhadap skor AIP setelah dikontrol oleh usia, asupan karbohidrat dan kondisi awal $(\mathrm{p}<0,05)$.
\end{abstract}

Kata kunci: HDL, jus buah jambu biji, skor AIP, trigliserida

\section{PENDAHULUAN}

Sumber Daya Manusia (SDM) yang sehat dan produktif akan meningkatkan keberhasilan suatu perusahaan. Terdapat beberapa masalah kesehatan yang terjadi pada pekerja yang berkaitan dengan gizi, higiene dan lingkungan (Widayana \& Wiratmaja 2014). Kondisi lingkungan udara yang semakin tercemar dapat memengaruhi kesehatan manusia, petugas tiket tol merupakan je- nis pekerjaan yang berisiko terpapar pencemaran udara seperti karbon monoksida (CO), senyawa Polycyclic Aromatic Hydrocarbon (PAH), nitrogen dioksida (NOx) dan Sulfur dioksida (SOx), partikulat debu dan timbal $(\mathrm{Pb})$ (Fitri \& Srisantyorini 2015; Kusminingrum 2010).

Paparan polusi udara yang terus menerus berkaitan dengan kematian dan kesakitan akibat penyakit pernafasan dan penyakit jantung. Penyakit tersebut terjadi karena polusi udara dapat

"Korespondensi: Surel: rivamustika86@gmail.com 
menyebabkan tingginya radikal bebas di dalam tubuh yang dapat menyebabkan terjadinya stres oksidatif (Eze 2015). Stres oksidatif dapat berpengaruh terhadap kadar profil lipid (Brucker 2014). Atherogenic Index of Plasma (AIP) merupakan suatu skor yang dapat dijadikan indikator untuk menduga risiko seseorang terkena penyakit jantung koroner. AIP didapatkan dari rumus $(\log ($ trigliserida/HDL $))$ dimana kadar trigliserida merupakan faktor risiko terjadinya penyakit jantung, sedangkan kolesterol HDL merupakan faktor proteksi (Dobiasova 2006). Pekerja yang terpapar polusi udara secara rutin mempunyai rata-rata skor AIP yang lebih tinggi yaitu 0,7 dibandingkan skor AIP pada kelompok kontrol yaitu 0,5 (Brucker 2014).

Konsumsi buah-buahan sangat dibutuhkan tubuh untuk menjaga profil lipid. Buah jambu biji merah merupakan buah lokal yang kaya akan antioksidan terutama vitamin C (50-300 mg/100 gr), serat, mineral, dan senyawa polifenol (Zabidah 2011). Penelitian pada tikus Sprague Dawley menunjukkan bahwa pemberian ekstrak buah jambu biji merah dengan dosis $0,398 \mathrm{mg} / \mathrm{g}$ selama 28 hari dapat menurunkan risiko penyakit jantung koroner dengan menurunkan skor AIP (Maryanto 2013). Konsumsi buah dalam bentuk jus merupakan salah satu alternatif dalam memenuhi kebutuhan antioksidan yang sangat praktis dan mudah dikonsumsi (Tonin 2015). Penelitian ini bertujuan untuk mempelajari pengaruh pemberian jus buah jambu biji merah (Psidium guajava L) terhadap skor AIP pada petugas tiket tol.

\section{METODE}

\section{Desain, tempat dan waktu}

Penelitian ini termasuk penelitian eksperimental dengan randomized pre-post control group design. Tempat penelitian di tiga gerbang tol (GT) di Kota semarang yaitu GT Tembalang, GT Manyaran dan GT Muktiharjo. Penelitian dilaksanakan pada bulan Oktober-November 2016.

\section{Jumlah dan cara pengambilan subjek}

Subjek dipilih dengan clustered random sampling pada tiga gerbang tol yang ada di Kota Semarang. Jumlah subjek ditentukan dengan menggunakan rumus besar sampel untuk beda rata-rata dua kelompok dengan hipotesis satu arah menggunakan $\alpha: 1,64$ dan power test:1,28 sehingga diperoleh 20 orang subjek pada tiap kelompok. Kriteria inklusi pada penelitian ini adalah bersedia menjadi subjek penelitian dengan menandatangani informed consent, pegawai PT Jasa Marga bagian petugas tiket tol, berdomisili di Kota Semarang, mempunyai masa kerja $>2$ tahun, umur 20-50 tahun, tidak memiliki penyakit diabetes mellitus, jantung, sindroma metabolik, tidak mengonsumsi suplemen antioksidan, tidak mengonsumsi obat penurun kolesterol, LDL dan trigliserida. Penelitian telah mendapatkan persetujuan Ethical Clearance dari Komisi Etik Fakultas Kedokteran Universitas Diponegoro dengan No. 945/EC/FK-RSDK/IX/2016.

\section{Tahapan Penelitian}

Tahapan awal penelitian adalah pengumpulan data yang dilakukan dengan cara pengukuran kadar trigliserida dan HDL subjek, kemudian dilakukan perhitungan skor AIP dengan rumus $(\log ($ trigliserida/HDL $))$. Pengukuran dilakukan pada awal dan akhir penelitian. Kadar trigliserida dianalisis menggunakan metode tes GPO sedangkan kadar HDL menggunakan metode CHOD PAP (Gandasoebrata 2013). Analisis kadar trigliserida dilakukan oleh laboratorium swasta di Kota Semarang.

Pengukuran asupan makan dengan metode recall $3 \times 24 \mathrm{jam} / \mathrm{minggu}$ selama 21 hari intervensi, selama penelitian tidak dilakukan kontrol terhadap asupan makanan subjek. Data berat badan (BB) dan tinggi badan (TB) diperoleh dengan pengukuran langsung. Data karakteristik subjek dikumpulkan dengan wawancara menggunakan kuesioner.

Tahapan selanjutnya adalah intervensi. Kelompok perlakuan diberi jus buah jambu biji merah sebanyak $250 \mathrm{ml}$ selama 21 hari dengan kandungan vitamin C $60 \mathrm{mg} / 250 \mathrm{ml}$ jus (berdasarkan hasil uji di Laboratorium Teknologi Pangan UNIKA Soegijapranata Semarang). Suplementasi vitamin $\mathrm{C}$ sebanyak $60 \mathrm{mg}$ selama 21 hari supaya vitamin $\mathrm{C}$ serum dalam darah stabil sehingga peran vitamin $\mathrm{C}$ sebagai antioksidan akan maksimal (Padayatti 2013). Jus buah jambu biji merah dibuat dari $120 \mathrm{~g}$ buah jambu ditambah $200 \mathrm{ml}$ air dan $4 \mathrm{~g}$ sorbitol.

\section{Pengolahan dan analisis data}

Data yang diperoleh ditampilkan dalam bentuk median (minimum-maksimum), rata-rata dan standar deviasi. Data asupan makanan diolah menggunakan nutrisurvey, dikonversikan menjadi asupan karbohidrat, lemak dan serat kemudian dibandingkan dengan kebutuhan dan dipersentasekan. Analisis data dilakukan dengan uji paired t-test, uji Wilcoxon, uji independent t-test, uji Mann Whitney dan uji multivariat general linear model. Nilai signifikan dalam penelitian ini jika variabel yang dianalisis memiliki nilai $\mathrm{p}<0,05$.

J. Gizi Pangan, Volume 12, Nomor 1, Maret 2017 
Jus bambu biji merah terhadap skor AIP

\section{HASIL DAN PEMBAHASAN}

\section{Karakteristik subjek}

Terdapat perbedaan karakteristik usia subjek dalam penelitian ini $(\mathrm{p}<0,05)$, dan tidak dapat dilakukan matching karena perbedaan usia subjek yang bekerja di gerbang tol Muktiharjo yaitu usia petugas tiket tol antara 20-30 tahun, sedangkan di Manyaran dan Tembalang antara 35-56 tahun. Umur subjek rata-rata pada kelompok perlakuan yaitu 40,8 tahun sedangkan pada kelompok perlakuan 34,8 tahun. Data karak-teristik selengkapnya dapat dilihat pada Tabel 1 .

Tidak terdapat perbedaan antara IMT kelompok perlakuan dan kelompok kontrol. Ratarata Indek Massa Tubuh pada kedua kelompok hampir sama.

Tabel 1. Sebaran subjek berdasarkan karakteristik

\begin{tabular}{cccc}
\hline Karakteristik & $\begin{array}{c}\text { Kelompok } \\
\text { kontrol } \\
(\mathrm{n}=20)\end{array}$ & $\begin{array}{c}\text { Kelompok } \\
\text { perlakuan } \\
(\mathrm{n}=20)\end{array}$ & $\mathrm{p}$ \\
\cline { 2 - 3 } & Rata-rata $\pm \mathrm{SD}$ & Rata-rata $\pm \mathrm{SD}$ & \\
\hline Usia (tahun) & $34.7 \pm 11,6$ & $40,8 \pm 9,5$ & $0,00^{\mathrm{a}}$ \\
IMT $\left(\mathrm{kg} / \mathrm{m}^{2}\right)$ & $24,5 \pm 2,7$ & $24,3 \pm 4,2$ & $0,48^{\mathrm{a}}$ \\
\hline${ }^{\mathrm{a}}$ uji independent t test; $\mathrm{IMT}=$ Indeks Massa Tubuh. &
\end{tabular}

\section{Tingkat asupan makanan subjek}

Asupan makanan merupakan salah satu faktor yang dapat memengaruhi skor AIP, diantaranya asupan karbohidrat, asupan lemak dan asupan serat. Tabel 2 menunjukkan bahwa terdapat perbedaan tingkat asupan karbohidrat pada kedua kelompok namun tidak terdapat perbedaan untuk tingkat asupan lemak dan tingkat asupan serat antara kedua kelompok.

Terdapat perbedaan tingkat asupan karbohidrat pada kelompok perlakuan dan kelompok kontrol $(p<0,05)$. Perbedaan ini terjadi karena rata-rata asupan pada kelompok perlakuan termasuk kategori baik $(82,4 \%)$ sedangkan pada kelompok kontrol termasuk kategori kurang $(69,3 \%)$. Setiap hari petugas tiket tol disediakan minuman teh dan kopi oleh perusahaan dalam cangkir yang besar dengan penambahan sekitar 2-3 sendok gula/penyajian, dan beberapa subjek dapat menghabiskan teh dan kopi lebih dari satu gelas di setiap waktu kerja. Asupan minuman tersebut berpengaruh besar terhadap jumlah asupan karbohidrat terutama karbohidrat sederhana. Konsumsi makanan tinggi karbohidrat akan meningkatkan laju lipogenensis dan esterifikasi asam lemak sehingga meningkatkan sintesis trigliserida dan sekresi Very Low Density Lipoprotein (VLDL). Konsumsi tinggi karbohidrat meningkatkan kadar trigliserida dan menurunkan kadar Kolesterol HDL (Dwi 2015).
Tabel 2. Sebaran subjek berdasarkan tingkat asupan

\begin{tabular}{lccc}
\hline \multirow{2}{*}{$\begin{array}{c}\text { Variabel } \\
(\%)\end{array}$} & $\begin{array}{c}\text { Kelompok } \\
\text { Kontrol } \\
(\mathrm{n}=20)\end{array}$ & $\begin{array}{c}\text { Kelompok } \\
\text { Perlakuan } \\
(\mathrm{n}=20)\end{array}$ & $\mathrm{p}$ \\
\cline { 2 - 3 } & Rata-rata $\pm \mathrm{SD}$ & Rata-rata $\pm \mathrm{SD}$ & \\
\hline Karbohidrat & $69,3 \pm 12,6$ & $82,4 \pm 17,09$ & $0,009^{\mathrm{a}}$ \\
Lemak & $140,5 \pm 92,7$ & $113,0 \pm 37,64$ & $0,296^{\mathrm{b}}$ \\
Serat & $57,3 \pm 11,6$ & $59,0 \pm 13,4$ & $0,67^{\mathrm{a}}$ \\
\hline${ }^{\mathrm{a}}$ uji independent $t$ test,${ }^{\mathrm{b}}$ uji Mann-Whitney. &
\end{tabular}

Tingkat asupan lemak pada kedua kelompok lebih dari $100 \%$, berdasarkan hasil wawancara makanan asupan lemak terbesar berasal dari makanan gorengan. Asupan sayur dan buah subjek masih kurang dari rekomendasi WHO, tingkat asupan serat pada kedua kelompok tergolong kurang hanya setengah dari kebutuhan yang seharusnya, hal ini sejalan dengan penelitian Kustiyah (2013) yang menjelaskan bahwa rata rata asupan serat pada orang dewasa hanya $19 \mathrm{~g} / \mathrm{hari}$.

Pengaruh pemberian jus buah jambu biji merah terhadap skor AIP sebelum dikontrol oleh usia, asupan karbohidrat dan kondisi awal.

Prediksi akan munculnya penyakit jantung koroner dapat didasarkan pada lipoprotein yang bersifat aterogenik yaitu trigliserida dan yang bersifat protektif yaitu Kolesterol HDL, prediksi tersebut dapat dihitung menggunakan rumus log (trigliserida/HDL). Studi case-control memperlihatkan bahwa seseorang yang terkena paparan polusi udara di perkotaan mempunyai keseimbangan lemak darah yang terganggu dengan tingginya kadar trigliserida dan rendahnya kadar HDL, hal ini berbeda sangat signifikan dengan kelompok kontrol yang tidak sering terpapar polusi udara (Kelishadi 2008).

Tabel 3 menunjukkan pengaruh pemberian jus jambu biji merah terhadap skor AIP, kadar trigliserida, dan kadar HDL. Hasil penelitian ini menunjukkan bahwa tidak terdapat pengaruh pemberian jus buah jambu biji merah terhadap skor AIP sebelum dikontrol oleh usia, tingkat asupan karbohidrat dan kondisi awal, serta tidak terdapat perbedaan diantara kedua kelompok $(p>0,05)$. Pengaruh jus buah jambu biji merah terhadap skor AIP mempunyai hasil yang tidak signifikan hal ini dikarenakan meskipun terjadi penurunan trigliserida tapi tidak diikuti oleh peningkatan HDL yang signifikan.

Hasil analisis statistik menunjukkan penurunan kadar trigliserida secara signifikan pada kelompok perlakuan setelah diberikan jus buah 
Anugrah dkk.

Tabel 3. Pengaruh pemberian jus buah jambu biji merah (Psidium guajava L.) terhadap skor AIP, kadar trigliserida, dan kadar HDL sebelum dikontrol oleh usia, tingkat asupan karbohidrat dan kondisi awal

\begin{tabular}{|c|c|c|c|c|c|c|c|}
\hline \multirow{2}{*}{ Variabel } & \multicolumn{3}{|c|}{ Kelompok kontrol } & \multicolumn{3}{|c|}{ Kelompok perlakuan } & \multirow{2}{*}{$\mathrm{p}$} \\
\hline & Min & Maks & Rata-rata \pm SD & Min & Maks & Rata-rata \pm SD & \\
\hline \multicolumn{8}{|l|}{ Skor AIP } \\
\hline Sebelum perlakuan & $-0,10$ & 1,28 & $0,56 \pm 0,37$ & $-0,6$ & 1,21 & $0,61 \pm 0,37$ & $0,727^{\mathrm{c}}$ \\
\hline \multirow[t]{2}{*}{ Setelah 21 hari } & 1,36 & 0,12 & $0,67 \pm 0,35$ & $-0,19$ & 1,09 & $0,49 \pm 0,36$ & $0,125^{\mathrm{c}}$ \\
\hline & & & $\mathrm{p}=0,086^{\mathrm{a}}$ & & & $\mathrm{p}=0,053^{\mathrm{a}}$ & \\
\hline \multicolumn{8}{|l|}{ Kadar trigliserida } \\
\hline Sebelum perlakuan $(\mathrm{mg} / \mathrm{dl})$ & 53 & 655 & $245,30 \pm 157,16$ & 42 & 595 & $223,75 \pm 157,92$ & $0,602^{\mathrm{d}}$ \\
\hline \multirow[t]{2}{*}{ Setelah 21 hari $(\mathrm{mg} / \mathrm{dl})$} & 72 & 794,2 & $280,65 \pm 205,96$ & 55 & 478 & $204,55 \pm 132,60$ & $0,615^{\mathrm{d}}$ \\
\hline & & & $\mathrm{p}=0,11^{\mathrm{b}}$ & & & $\mathrm{p}=0,01^{\mathrm{a}}$ & \\
\hline \multicolumn{8}{|l|}{ Kadar HDL } \\
\hline Sebelum perlakuan (mg/dl) & 33 & 80 & $49,55 \pm 12,28$ & 34 & 74 & $48,65 \pm 10,499$ & $0,805 \mathrm{c}$ \\
\hline \multirow[t]{2}{*}{ Setelah 21 hari $(\mathrm{mg} / \mathrm{dl})$} & 32 & 79 & $47,90 \pm 12,21$ & 35 & 74 & $50,30 \pm 11,67$ & $0,529 \mathrm{c}$ \\
\hline & & & $\mathrm{p}=0,058^{\mathrm{a}}$ & & & $\mathrm{p}=0,338^{\mathrm{b}}$ & \\
\hline
\end{tabular}

${ }^{a}$ uji Paired t test $;{ }^{b}$ uji willcoxon; ${ }^{c}$ uji independent $t$-test $;{ }^{d}$ uji mann whitney.

jambu biji merah $(\mathrm{p}<0,05)$. Namun penurunan ini tidak memberikan perbedaan antara kedua kelompok. Rata rata kadar trigliserida subjek pada kedua kelompok baik sebelum ataupun sesudah pemberian jus buah jambu biji merah menunjukkan nilai diatas normal yaitu $<150 \mathrm{mg} / \mathrm{dl}$. Hal ini dapat diakibatkan oleh subjek mempunyai kebiasaan rutin mengonsumsi teh manis/kopi dalam jumlah besar serta memakan makanan gorengan yang berbahan dasar tepung, hal ini sejalan dengan penelitian sebelumnya pada pegawai tambang di Provinsi Kalimantan yang menunjukkan bahwa pegawai yang rutin mengonsumsi makanan gorengan dengan bahan dasar tepung memiliki kadar trigliserida yang tinggi (Sartika 2011).

Berdasarkan Tabel 2 tingkat asupan karbohidrat pada kelompok perlakuan lebih tinggi dibandingkan dengan kelompok kontrol, asupan karbohidrat terutama karbohidrat sederhana yang tinggi berpengaruh secara tidak langsung pada kadar trigliserida. Senyawa trigliserida yaitu jenis lemak yang biasanya dijumpai di dalam darah yang mengandung glukosa lebih. Kadar trigliserida tinggi dan HDL rendah maka akan berpengaruh pada aterosklerosis dan berimbas pada penyakit jantung (Dwi 2015). Selain itu penyebab kadar trigliserida yang tinggi dapat diakibatkan oleh makanan-makanan yang berbahan dasar tepung-tepungan. Namun demikian, meski asupan karbohidrat lebih tinggi pada kelompok perlakuan, pemberian jus buah jambu biji selama 21 hari mampu menurunkan kadar trigliserida.
Serat yang terkandung dalam jus buah jambu biji merah merupakan serat larut air yang dapat menurunkan risiko penyakit kardiovaskular dengan menurunkan kadar lipid di dalam plasma. Serat larut air dapat memiliki efek hipotrigliseridemia, meskipun mekanisme hipotrigliseridemia ini belum dapat diterangkan secara jelas, tetapi serat larut air konsisten dapat menyebabkan penundaan absorbsi trigliserida dan gula dari usus halus. Serat juga memiliki efek menurunkan indeks glikemik yang juga dapat berperan dalam penurunan kadar plasma lipid. Indeks glikemik yang rendah dapat menurunkan resistensi insulin dan kadar insulin sehingga menyebabkan penurunan asam lemak bebas yang dapat mencegah akumulasi trigliserida dalam darah (Galisteo 2008).

Hasil penelitian menunjukkan tidak ada perbedaan kadar HDL kolesterol setelah diberikan jus buah jambu biji dan tidak terdapat perbedaan antara dua kelompok ( $p>0,05)$, meskipun secara statistik tidak menunjukkan adanya perbedaan namun kadar rata-rata kolesterol HDL kelompok perlakuan meningkat sebanyak 1,65 $\mathrm{mg} / \mathrm{dl}$ sedangkan pada kelompok kontrol terjadi penurunan rata-rata kadar kolesterol HDL yaitu sebesar 1,65 mg/dl. Rata-rata asupan lemak subjek pada kelompok perlakuan yaitu 113,01\% dan pada kelompok kontrol 140,47\%. Asupan lemak terutama lemak jenuh dan lemak trans dapat menurunkan kadar HDL kolesterol, asupan lemak terbesar berasal dari makanan gorengan. 
Hasil wawancara makanan menggunakan metode recall $3 \times 24$ jam menunjukan bahwa responden pada kedua kelompok mempunyai kebiasan makanan gorengan seperti pisang goreng, bakwan, mendoan, kerupuk, rempeyek, berbagai macam biskuit, roti, cake dan cookies, makanan tersebut mengandung asam lemak trans yang diperoleh dari proses penggorengan ataupun dari bahan pembuatan seperti margarin. Asam lemak trans terdapat pada makanan nabati yang telah mengalami proses penggorengan yang sering dikonsumsi masyarakat Indonesia. Menurut hasil analisis laboratorium di Institut Pertanian Bogor, makanan jajanan yang sering dikonsumsi masyarakat di Kota Semarang mengandung asam lemak trans antara 0,09-22,4\% (Tjahjono 2014).

Pengaruh asam lemak trans pada metabolisme lipoprotein yaitu asam lemak trans mampu menghambat kerja dari enzim lecithin cholesterol acyltransferase (LCAT) yang berperan mengeluarkan kolesterol dari lipoprotein dan jaringan. Hal ini mengakibatkan HDL tidak terbentuk dan kolesterol yang berlebihan tidak dapat diangkat kembali ke hati sehingga terjadi penurunan kadar HDL dan HDL tidak berfungsi dengan baik. Selain itu asam lemak trans dapat juga menyebabkan kenaikan kadar trigliserida dibandingkan dengan jenis asam lemak lainnya (Murray 2014). Analisis inilah yang mendasari penyebab terjadinya kenaikan HDL tidak signifikan pada kelompok perlakuan, karena meskipun mereka mengonsumsi jus jambu selama 21 hari tetapi tidak melakukan pembatasan asupan makanan sumber asam lemak trans.

\section{Pengaruh pemberian jus buah jambu biji merah terhadap skor AIP setelah dikontrol oleh usia, asupan karbohidrat, dan kondisi awal.}

Gambar 1 memperlihatkan hasil uji multivariat general linear model, rata-rata skor AIP kelompok perlakuan adalah $0,49 \pm 0,02$ sedangkan rata-rata skor AIP kelompok kontrol lebih tinggi yaitu $0,69 \pm 0,2$. Terdapat hubungan yang signifikan pemberian jus buah jambu biji merah selama 21 hari terhadap skor AIP $(\mathrm{p}=0,02)$ setelah dikontrol oleh usia, asupan karbohidrat dan kondisi awal dengan $R$ adjustment sebesar 0,559, artinya pengaruh usia, tingkat asupan karbohidrat dan kondisi awal terhadap skor AIP sebesar 55,9\% dan sisanya dipengaruhi oleh variabel lain.

Penelitian ini menunjukkan bahwa vitamin $\mathrm{C}$ dan serat yang terkandung dalam jus buah jambu biji merah sangat baik untuk menurunkan kadar trigliserida, hal ini sejalan dengan peneli- tian Hermsdorff (2012) yang melaporkan bahwa terdapat penurunan kadar trigliserida pada subjek yang diberikan suplementasi vitamin C. Jus buah jambu biji yang mengandung vitamin $\mathrm{C}$ berperan sebagai homeostatis dengan menurunkan kadar trigliserida yang tinggi, tetapi tidak menurunkan kadar trigliserida dalam kategori normal (Eteng 2007). Jus buah jambu biji kaya akan serat makanan, selain itu buah jambu biji juga me-ngandung magnesium dan kalium. Magnesium dapat memperbaiki kadar kolesterol total, LDL, dan trigliserida, serta meningkatkan HDL (Chao et al. 2013).

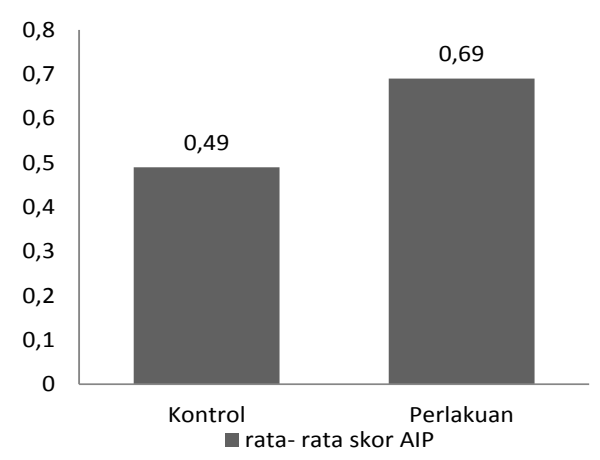

Gambar 1. Hasil uji multivariat general linear model

Penelitian ini mempunyai beberapa keterbatasan yaitu recall yang dilakukan hanya pada saat penelitian sehingga tidak dapat dinilai perubahan pola makan subjek sebelum mengikuti penelitian dan saat mengikuti penelitian. Selain itu subjek yang bersedia mengikuti penelitian ini mempunyai motivasi yang lebih tinggi dibandingkan subjek yang tidak mengikuti penelitian. Kedua keterbatasan ini tidak mengganggu validitas internal hasil penelitian karena kedua kelompok homogen kecuali pada asupan karbohidrat dan usia yang sudah dikontrol pada analisis multivariat.

\section{KESIMPULAN}

Penelitian ini menunjukkan terdapat perbedaan usia subjek antara kelompok perlakuan dan kelompok kontrol dimana rata-rata usia kelompok perlakuan lebih tua daripada kelompok kontrol $(\mathrm{p}<0,05)$. Tingkat asupan karbohidrat pada kelompok perlakuan lebih tinggi dibandingkan kelompok kontrol dan terdapat perbedaan antara keduanya $(\mathrm{p}<0,05)$. Usia dan tingkat asupan karbohidrat merupakan variabel perancu yang dapat dianalisa secara multivariat karena uji beda menunjukkan hasil yang signifikan. 
Meskipun usia pada kelompok perlakuan lebih tua dan tingkat asupan karbohidrat lebih tinggi namun penelitian menunjukkan bahwa pemberian jus buah jambu biji sebanyak $250 \mathrm{ml}$ selama 21 hari yang mengandung $60 \mathrm{mg}$ vitamin $\mathrm{C}$, mengandung serat, mineral, vitamin lainnya dan senyawa-senyawa fitokimia secara signifikan mampu menurunkan risiko penyakit jantung melalui penurunan skor AIP.

\section{DAFTAR PUSTAKA}

Brucker N, Charo MF, Moro AM, et al. 2014. Atherosclerotic process in taxi drivers occupationally exposed to air pollution and co-morbidities. Environ Res 131:31-38. http//doi:10.1016/j.envres.2014.02.012.

Chao H, Wu P, Lo D, Wu W, Wu M. 2013. Effect of guava ( Psidium guajava L) fruit water extract on lipid peroxidation and serum lipid profiles of streptozotocin-nicotinamide induced diabetic rat. Journal of pharmacy and pharmacology 7(32):2299-2305. http// doi:10.5897/AJPP2013.3698.

Dobiasova. 2006. Atherogenic Index of plasma ( $\log ($ triglycerides/HDL-Cholesterol). Theoritical and implication. Clin Chem 50(7):1113-1115.

Dwi RSN. 2015. Hubungan asupan karbohidrat dan lemak dengan kadar profil lipid pada pasien jantung koroner rawat jalan di RSUD Dr. Moewardi Surakarta. Naskah Publikasi Universitas Muhamddiyah Surakarta.

Eze IC, Schaffner E, Foraster M. 2015. Longterm exposure to ambient air pollution and metabolic syndrome in adults. PLoS One 10(6):1-19. http//doi:10.1371/journal. pone. 0130307 .

Eteng MU, Ibekwe HA, Amatey HE, Bassey BJ, Uboh Fu. 2007. Effect of vitamin $\mathrm{C}$ on serum lipids and electroyte profile of albino wistar rats. Nutr Journal 21(1-2):15-19.

Fitri E \& Srisantyorini T.2015. Gambaran dan cara pengendalian paparan timbal $(\mathrm{Pb})$ yang dialami tiket tol di Serang Timur Banten. Jurnal kedokteran dan kesehatan 11(1):1-117.

Galisteo M, Duarte JZA. 2008. Effects of dietary fibers on disturbances clustered in the metabolic syndrome. J Nutr Biochem 19(2):71-84.

Gandasoebrata R. 2013 Penuntun Laboratorium Klinik. Jakarta: Dian Rakyat.
Hermsdorff HHM, Barbosa KBF, Volp ACP, Puchau B, Mart1 JA, Bressan J. 2012. Vitamin $\mathrm{C}$ and fibre consumption from fruits and vegetables improves oxidative stress markers in healthy young adults. British Journal of Nutrition 107(8):1119-1127. http//doi:10.1017/S0007113411004235.

Kelishadi R, Poursafa P, Health C.2008. Impact of climate change and air pollution on dyslipidemia and the components of metabolic syndrome. In Dyslipidemia-From Prevention to Treatment. InTech.

Kusminingrum N dan Gunawan G.2010. Polusi Udara Akibat Aktivitas Kendaraan Bermotor di Jalan PerKotaan Pulau Jawa dan Bali. Bandung: Puslitbang Jalan dan Jembatan.

Kustiyah L, Widhianti MU, Dewi M. 2013. Hubungan asupan serat dengan status gizi dan profil lipid darah pada orang dewasa dislipidemia. J Gizi Pangan 8(3):193-200.

Maryanto S. 2013. The effects of red guava (Psidium guajava $\mathrm{L}$ ) fruits on lipid peroxidation in hypercholesterolemic rats 2(11):116121.

Murray RK, Granner DK MP.2014.Biosynthesis of Fatty Acids 24th ed. London: Harpers Biochemistry.

Padayatty S, Katz A, Wang Y, et al. 2013. Vitamin $\mathrm{C}$ as an antioxidant: Evaluation of its role in disease prevention. J Am Coll Nutr 22(1):18-35. doi:10.1080/07315724.2003. 10719272.

Tonin FS, Steimbach LM, Wiens A, Perlin CM, Pontarolo R. 2015. Impact of natural juice consumption on plasma antioxidant status: A Systematic Review and Meta-Analysis: 22146-22156.

Sartika RAD. 2011. Effects of trans fatty acids intake on blood lipid profile of workers in East Kalimantan. Mal J Nutr 17(1):119127.

Tjahjono KDK. 2014. Analisis Kandungan Asam Lemak Trans pada Makanan Jananan di Kota Semarang. Institut Pertanian Bogor.

Widayana dan Wiratmaja. 2014. Kesehatan dan Keselamatan Kerja. Yogyakarta: Graha Ilmu.

Zabidah, Kong KW. 2011. Antioxidant properties of tropical juices and their effects on in vitro hemoglobin and low density lipoprotein (LDL) oxidations (18):549-56. 